\title{
MENARA KUDUS: IS IT A MINARET OR A TEMPLE? A STUDY OF ARCHITECTURAL ACCULTURATION
}

\section{Ashadi Ashadi}

Department of Architecture

Universitas Muhammadiyah Jakarta

Jakarta, Indonesia

ashadi@ftumj.ac.id

\begin{abstract}
Menara Kudus is a minaret building property of an old mosque in Kudus city, Indonesia. The shape of the minaret building is unique and different from the shape of the mosque minarets in general, both in Indonesia and in the Islamic world; The shape of the building is more similar to a Hindu / Buddhist temple building in Java. This paper aims to find answers to questions raised by some scientists about the status of the Menara Kudus building; Is it a temple building that has changed its function, or is it a mosque minaret building How is the architectural acculturation of the Menara Kudus building? The method used was comparative descriptive to describe the Menara Kudus, the Hindu / Buddhist temples, and the minaret of the old mosque. The comparative method compares the Menara Kudus building with the temple and the mosque minaret to get similarities and differences. The result is that the Menara Kudus is thought to be a temple building that has changed its function. There has been architectural acculturation, a mixture of local and nonlocal elements.
\end{abstract}

\section{KEYWORDS:}

Architectural acculturation; Minaret; Temple; Local; Non-Local

\section{INTRODUCTION}

Menara Kudus is a minaret building that complemented the old mosque in Kudus city, Indonesia. That minaret became a symbol of the identity of the Kudus city as well historical monuments. It was a building of antiquity like a Hindu temple [Figure 1-4].

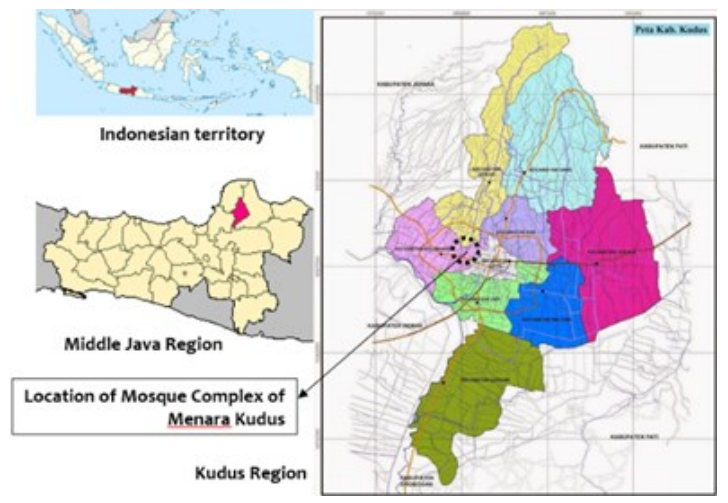

Figure 1. Map of Kudus City

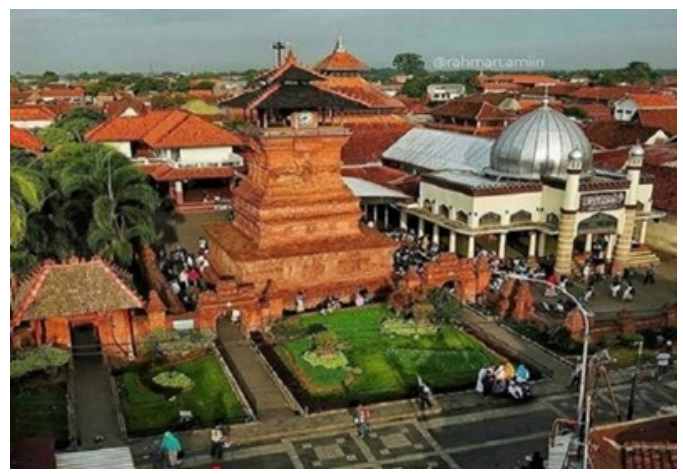

Figure 2. Mosque Complex of Menara Kudus

Kudus is one of the cities in the Islamic world included in UNESCO's monitoring as a conservation city located in Central Java, Indonesia. Kudus is a unique city because many Islamic buildings were influenced by Hindu Javanese culture, including the minaret of the old mosque in the city [1]. 


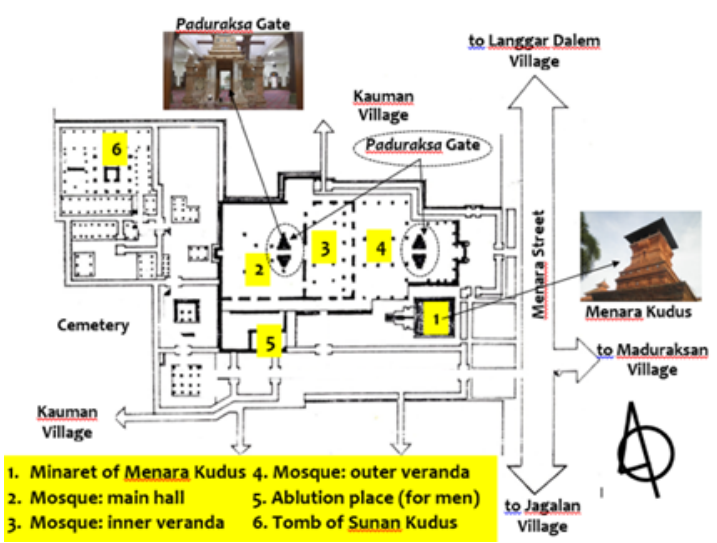

Figure 3. Plan of Mosque Complex of Menara Kudus [Author]

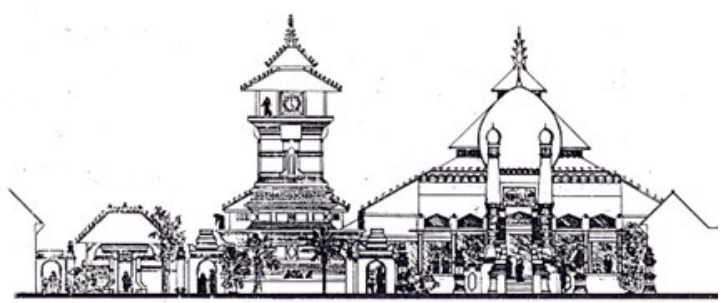

Figure 4. East Elevation of the Mosque Complex [Author]

Menara Kudus building, with its uniqueness, became a matter of debate among scientists, especially concerning its status as a worship building. Was it originally a building for worshiping people before Islam (Hinduism) - a temple - or since its establishment, it had become a symbol of Islamic worship - the mosque's minaret. For those who were more inclined to the first opinion, most assumed that the building of the Menara Kudus was initially a temple changed its function later. It could be compared to the temple buildings in East Java. At a glance, the shape of the Menara Kudus building was indeed similar to some temples in East Java. It was based on the architecture history before and the beginning of the Islam development in Java. It was in the Hindu period that ended at the Majapahit kingdom. It was influenced both the architectural form and its ornaments. If the Menara Kudus was related to its function to call and gather people (call to prayer) adzan, this building could be compared to the Bale Kul $\mathrm{Kul}$ in Bali [Figure 5]. The second opinion was based on the temporary fact that the orientation of the Menara Kudus building was the same as the orientation of the mosque building-[2][3].

Menara Kudus was an architectural work that involved cultural aspects. The architectural form of the Menara Kudus was thought to be a form of cultural mixing or acculturation between Hindu and Islamic cultures. Hindu-style buildings such as the two paduraksa gate in the mosque and kala decoration at the ablution place in the complex of Menara Kudus [Figure 6]. Many Hindu-style buildings made the mosque of Menara Kudus the only mosque in Java with intense acculturation between Hindu and Islamic cultures.

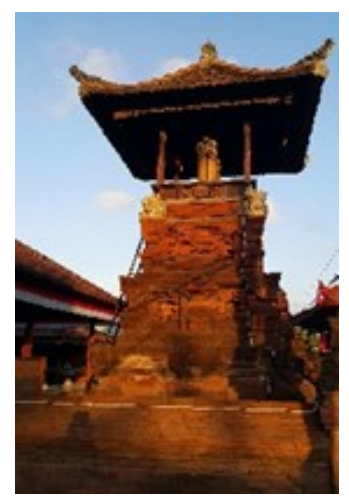

Figure 5. Bale Kul Kul in Bali [Author]

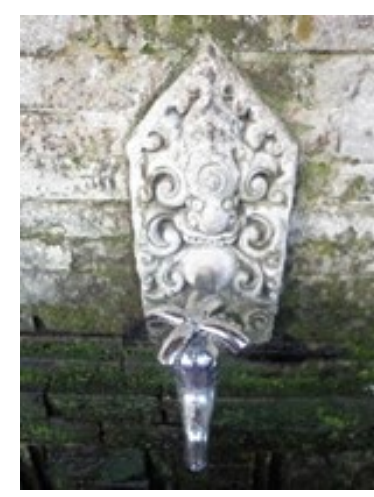

Figure 6. "Kala" decoration at the ablution place of the mosque [AUthor]

As explained above, many problems had arisen regarding the status of the Menara Kudus building. Was it a Hindu temple that functioned later as a minaret as the completeness of the mosque? Or indeed a minaret of the mosque made by Muslims from the beginning? How the architectural acculturation of the Menara Kudus building happened?

\section{METHODS}

This study uses the comparative descriptive method to analyze the research problem. The method is used to describe the Menara Kudus building, several Hindu temples in East Java, and several minarets of an old mosque in Java, based on field observations and literature study (about the temples and the old mosque in Java, and the architectural acculturation). The description includes the history of its establishment, architectural forms, and ornament. There are accompanied by illustrations and photos to clarify the description. The comparative method is done by comparing the building of the Menara Kudus with some temples in East Java, especially in the Majapahit kingdom period. With some minarets of the old mosque in Java, to get similarities and differences. The Menara Kudus is compared to the Hindu temple and the minaret of the old mosque in Java. The results of this comparison will be interpreted how the architectural acculturation process takes place, and the status of the Menara Kudus building is; Whether it is a Hindu temple building or a mosque minaret [Figure 7-9]. 


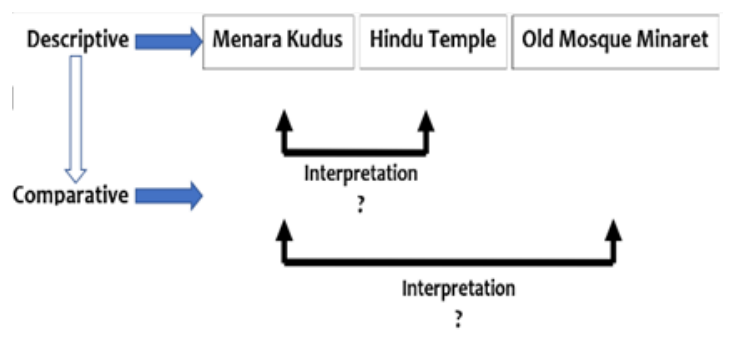

Figure 7. The method diagram [Author]

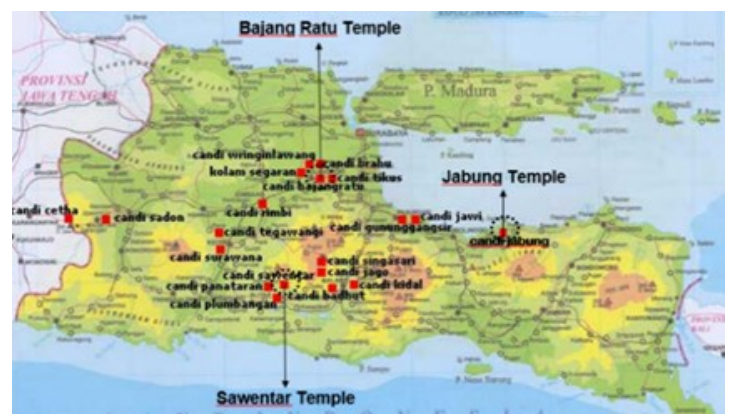

Figure 8. Map of temples location in East Java

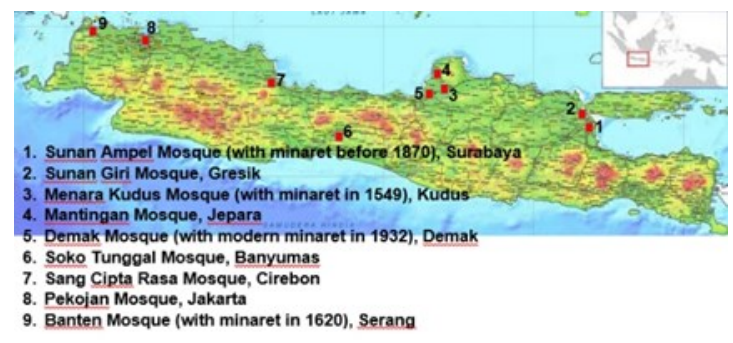

Figure 9. Location of Several Old Mosques in Java [Author]

\section{DISCUSSION \\ MENARA KUDUS}

The Menara Kudus was established during the Islamic kingdom of Demak in the 16th century AD. Based on the inscription above the mosque's mihrab, the Menara Kudus was established in conjunction with the mosque's establishment in 956 Hijriyah in the Islamic calendar or 1549 AD [4] [5].

The Menara Kudus building can be divided into three parts: the leg or foot, body, and head. Overall, the building's shape from all three sides: east, south, and north, looks the same. On the west side of the building, there is a stair to the minaret room. The top of the minaret is a wooden building with a tajug roof [Figure 10 and Figure 11].

The base part of the foot of the minaret (Sub Basement) has a square plan with a size of $10.5 \times 10.5$ $\mathrm{m} 2$, height $1.25 \mathrm{~m}$. The plan becomes smaller from the Sub Basement to the top of the foot, with $9.5 \times 9.5 \mathrm{~m}^{2}$. The height of the foot is approximately $4.50 \mathrm{~m}$. There is a vertical hole $\left(1.5 \times 1.5 \mathrm{~m}^{2}\right)$ in the building center to reach the minaret's top from a height of 7-12 meters [Figure 12]. In this hole, there is a wooden ladder. The minaret's head is a wooden building with a height of
$2.5 \mathrm{~m}$; the top is a two-slayer tajug roof with a $2.5 \mathrm{~m}$ height. At the top is the crown (memolo), with a height of approximately $1 \mathrm{~m}$. Overall the Menara Kudus building has a height of approximately $18 \mathrm{~m}$. [Figure 13].

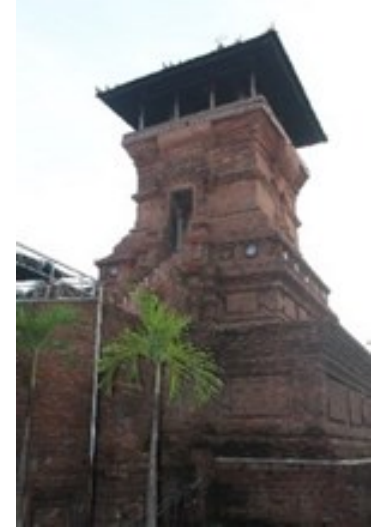

Figure 10. Menara Kudus Building [Author]
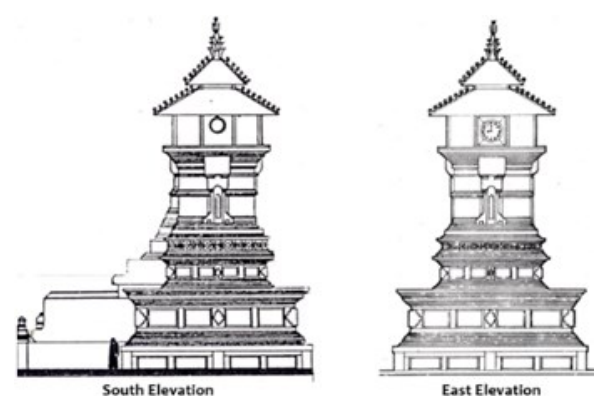

Figure 11. Elevation of Menara Kudus [Author]

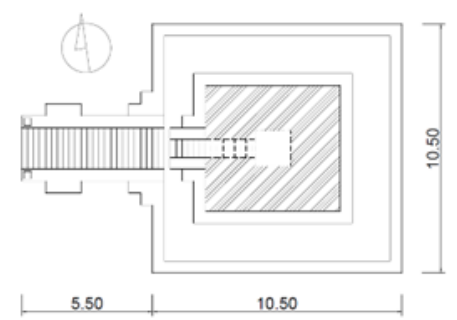

Figure 12. Plan of Menara Kudus [Author]

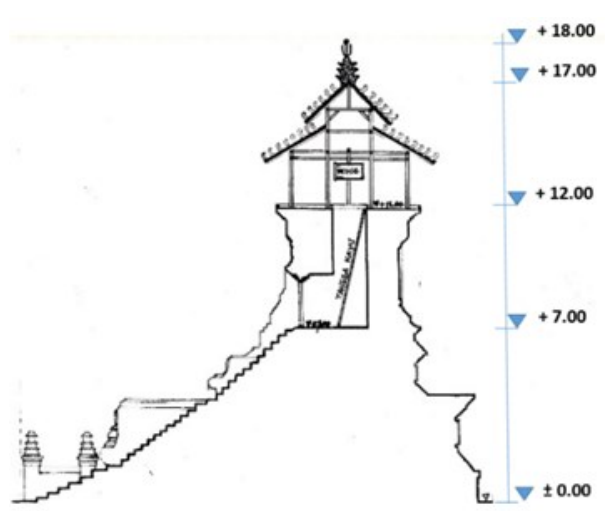

Figure 13. Section of Menara Kudus [Author] 


\section{HINDU TEMPLE IN EAST JAVA IN THE PERIOD OF MAJAPAHIT} KINGDOM

The word "Candi" - temple - comes from the word "Candika," which refers to the name Durga as the Goddess of Death. The primary function of the temple shows its type. First, the temple functioned to glorify Goddess Durga, Brahma, Vishnu, and Shiva [6][7][8]; Example of Prambanan temple in Sleman, Yogyakarta. Second, the temple functioned to honor and glorify a king or prominent people; Examples of Jago Temple (for King Wisnuwardhana) and Kidal Temple (for King Anusapati) in Malang, East Java. Third, the temple functioned as a place of worship; An example of the Penataran temple in Blitar, East Java. Fourth, the temple functioned as a haven for the king or prominent person; for example, the Sawentar temple in Blitar and Jabung temple in Probolinggo, East Java (stopover of king Hayam Wuruk). Fifth, the temple functioned as a monastery; Examples of Sari temple and Plaosan temple in Sleman, Yogyakarta. Sixth, the temple functioned as a "gapura" (gate); examples of the Bajang Ratu temple and Wringin Lawang temple in Mojokerto (formerly known as Trowulan, the capital city of Majapahit kingdom), East Java [9][10][11] [Figure 14].

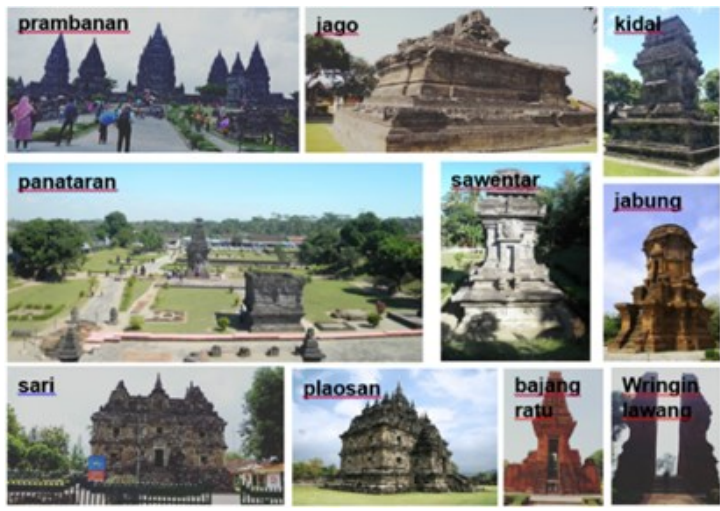

Figure 14. Several Temples in Central and East Java according to their functions [Author]

In the Majapahit kingdom period, in the 13th to 15th centuries, several temples were erected. The important ones were the Sawentar temple in Blitar, the Jabung temple in Probolinggo, and Bajang Ratu temple in Mojokerto. In this paper, the three temples were used as a comparison of the Menara Kudus building. [Figure 15]. The selection of these temples as objects of comparison was based on the criteria: first, they were built during the Majapahit kingdom era [12], a period very close to the early days of Islam in Java; second, they were tall and slender; and third, they were incomplete and good condition. Among the three temples, the most complete and good condition was the Sawentar temple. Therefore, it was a temple compared to the Menara Kudus building.

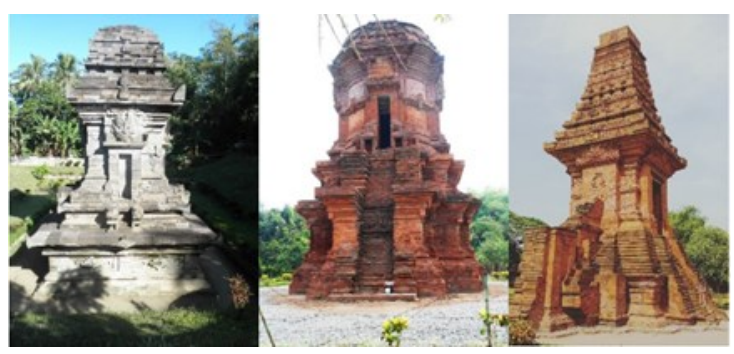

Figure 15. Sawentar temple (left), Jabung temple (central), Bajang Ratu temple (right) [Author]

Sawentar Temple was allegedly founded at the beginning of the Majapahit Kingdom. The relief of Majapahit Solar showed it on the inside of the temple's roof cover, a symbol of the Majapahit kingdom. There was a relief of a cock's wing at the bottom of the temple near the entrance steps. The cock was a symbol of Hayam Wuruk, king of Majapahit. [Figure 16 and Figure 17].

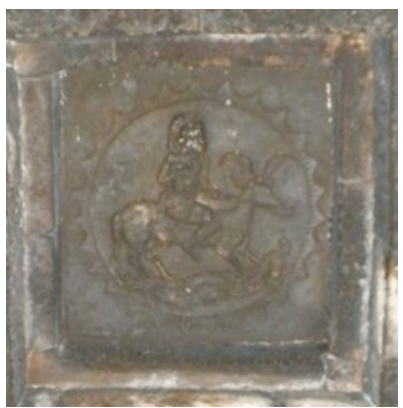

Figure 16. Relief of Majapahit Solar: Sawentar Temple [Author]

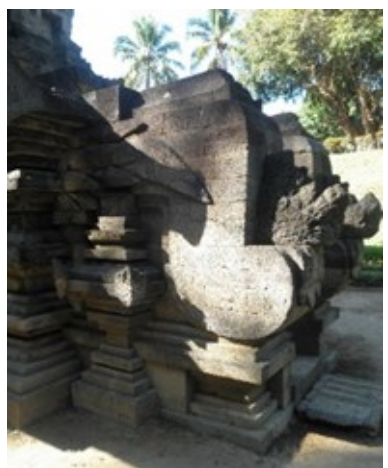

Figure 17. Relief of a cock's wing: Sawentar Temple [Author]

The body of the Sawentar temple stands on a temple foot measuring about $7 \times 7 \mathrm{~m}^{2}$, with a height of about $1.5 \mathrm{~m}$. The height of the temple to its peak reaches $10.65 \mathrm{~m}$. On the outer walls of the temple's body, on three sides: North, East, and South, there are niches almost the same size as the door opening. Above these niches are sculptures - kala. Part of the temple roof partially collapsed, especially at its peak. The original shape of the peak is thought to be cube-shaped. On the roof of the temple, there are reliefs meander patterned, naturalist, and motifs of tumpal. The roof shape of Sawentar Temple has similarities with Candi Kidal. 
The Jabung temple in the Nagarakertagama, was called Bajrajinaparamitapura; King Hayam Wuruk visited it on East Java in 1359 AD. Based on an inscription on the entrance gate of the Jabung temple, it was established in 1276 Saka (1354 AD) during the early reign of King Hayam Wuruk. [13].

The Jabung temple building comprises bricks, measuring $13.13 \mathrm{~m}$ long, $9.60 \mathrm{~m}$ wide, and $15.58 \mathrm{~m}$ high. The architecture of the Jabung Temple is exciting, consisting of the batur, legs, body, and roof, on the round body shape (octagonal cylinder) standing on the temple foot. The uniqueness of the Jabung Temple is the cylindrical body of the temple. Above the door is the sculpture - kala. The roof of the dagoda (stupa) has collapsed, and the top is decorated with sulur-suluran motifs.

Bajang Ratu temple was established in the 14th century; The temple was built for King Jayanegara, who died in 1328 AD. It was based on at least two pointers. The first pointer, the shape of the Bajang Ratu temple, was similar to the shape of the Berangka Tahun temple in the Panataran Temple complex in Blitar. The second, the decorative relief on the door frame of the Bajang Ratu temple, was similar to the Ramayana relief in Panataran Temple [14].

The temple building of Bajang Ratu has a height of $16.1 \mathrm{~m}$ and a length of $6.74 \mathrm{~m}$; On the right and left, there are wings. On each side of the steps are decorations of lions and long-eared animals. On the footwall of the temple, there is a relief of Sri Tanjung. On the right and left of the front wall, there are Ramayana reliefs. Above the door, there is a relief of kala [Figure 18]. The temple roof in the form of meru (mountain) consists of nine levels with a square top.

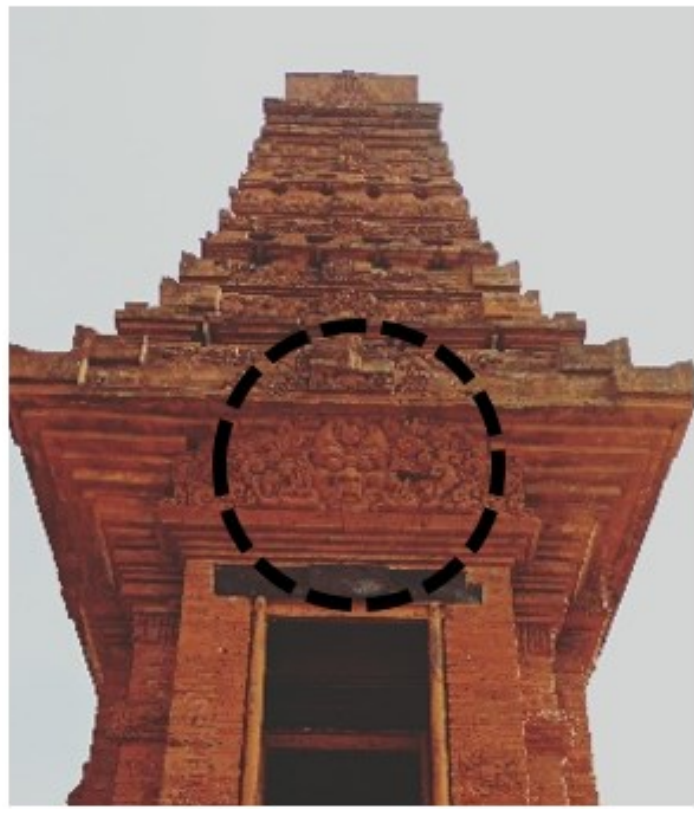

Figure 18. Relief of "kala" above the door: Bajang Ratu Temple [Author]

\section{MINARET OF OLD MOSQUES IN JAVA}

The spread of Islam in Java carried out by Walisongo began around the $15^{\text {th }}$ AD century, which was then continued by the sultans of the Islamic kingdom. The merchants had left many artifacts on this island, especially the mosque.

In Java, three old mosques also have old minarets, namely Banten Mosque in Serang, West Java, Sunan Ampel Mosque in Surabaya, East Java, and AnNawir Mosque Jakarta. That three minarets are similar in shape. They are cylindrical [Figure 19]. The three minarets are used to compare the Menara Kudus building, considering that their period is not far from the period of the existence of the Menara Kudus building.

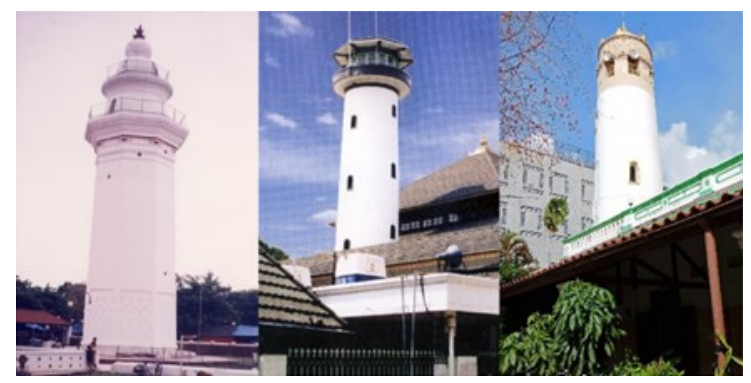

Figure 19. Minaret of Banten mosque (left), Minaret of Sunan Ampel mosque (central), Minaret of A Nawier mosque (right) [Author]

Banten Mosque was founded in 1556 by Sultan Maulana Hasanuddin (1552-1570) [Figure 20], the first sultan of the Sultanate of Banten. At the same time, the minaret of the mosque was built in 1620 by a Dutch architect, Hendrik Lucazoon Cardeel. Besides being used as a place to make the call to prayer-adzan, the minaret was used as a place to store weapons.

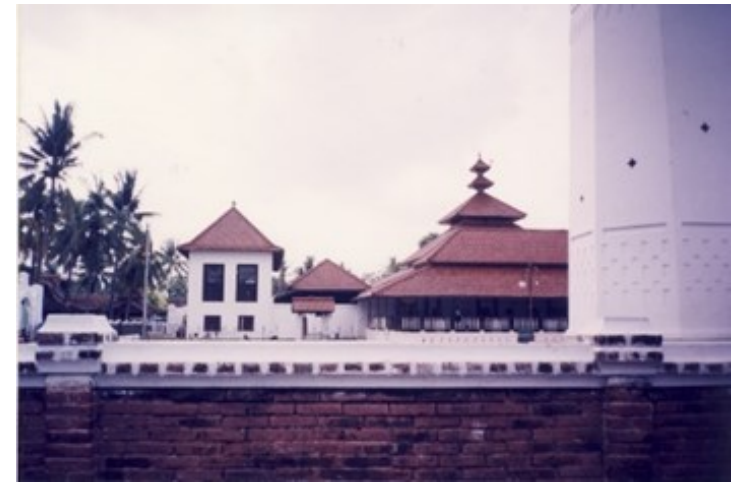

Figure 20. Mosque of Banten [Author]

The minaret is made of plastered bricks and painted white with a height of $24 \mathrm{~m}$, with a bottom diameter of $10 \mathrm{~m}$. The minaret is divided into three parts, namely foot, body, and head. The foot in the form of octagonal consists of two layers. The first layer is $33 \mathrm{~cm}$ high. The second layer is located above the first layer, height $27 \mathrm{~cm}$. The body is octagonal and shrinks at the top. The head of the minaret consists of two levels. The first level is dome-shaped and has an octagonal terrace with a metal fence around it. The 
second level is a dome smaller than the first level dome, round. At the top of the minaret, there is a crown (Memolo). The minaret is reminiscent of the shape of the Dutch lighthouse [15][16].

Sunan Ampel Mosque was built in the $15^{\text {th }}$ century $A D$ in a simple building made of wood. The minaret building added later was not known when it was first built. Based on the ancient image, until 1870, the minaret building had a dome-shaped roof. Then it was replaced with an octagonal shape in 1910. At the bottom of the dome, there were columns arranged in a circle according to the tower's shape [17].

The shape of the minaret of the Sunan Ampel Mosque is the result of changes in 2012. The head of the minaret is added to the hallway that surrounds it. The addition of this hallway causes the details under the column to become invisible, replaced by glass doors that formed an octagon, similar to the minaret's roof shape of the roof of the minaret. The minaret has a cylindrical shape with a height reaching $24 \mathrm{~m}$, which penetrates the mosque's roof. There are details in the form of vertical and horizontal lines surrounding the minaret at the bottom of the tower's column, while there are lines at the top of the column [Figure 21].

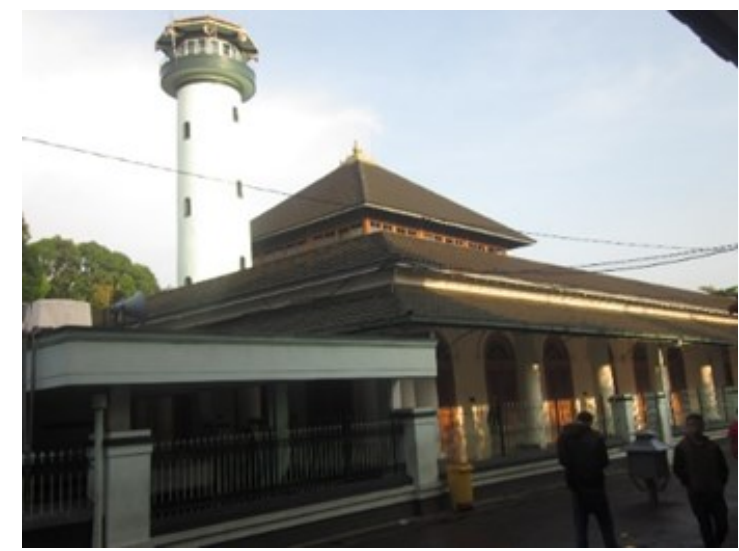

Figure 21. Mosque of Sunan Ampel [Photo: Ashadi]

A Nawier Mosque was built by Sayid Abdullah bin Husein Alaydrus who came from Hadhramaut, Yemen, in 1760 , in the Pekojan region, West Jakarta. This mosque was considered a symbol of Arab civilization in Jakarta. Pekojan was one of the historical places in Jakarta. Pekojan came from the word koja or khoja, a term used to refer to people of Indian descent who were Muslim. This village was later known as the Arab village because the Dutch East Indies Government in the 18th century once obliged immigrants from Hadramaut (South Yemen) to stay here first. Sayid Abdullah bin Husein Alaydrus himself came from Hadramaut.

An Nawier Mosque is also known as the Pekojan Mosque. In the Pekojan area, there are many old mosques. Besides the An Nawier Mosque, Al Anshor mosque, Kampung Baru mosque, Az Zawiyah mosque, Ar Raudah mosque, and Langgar Tinggi mosque. Among these, only the An Nawier mosque has a minaret building. [Figure 22 dan Figure 23].

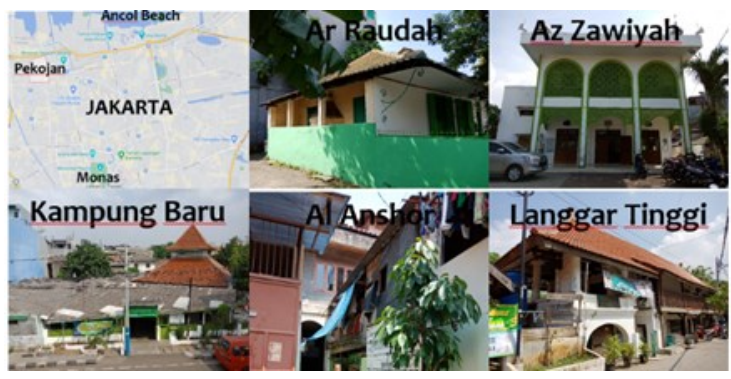

Figure 22. Mosques in the Pekojan Area [Author]

The minaret building is divided into three parts. The first, as high as 4 meters, is rectangular. The second, 9.6 meters high, is round with four windows with a semicircular curved top. The third is a cylindrical round shape, which is smaller as high as 2.4 meters, the top covered with a 1-meter high conical roof. In the half of the minaret, there is a rhomboid hole around the sphere of the building. At the top of the building, there are six windows with a semicircular curved top. In the sixth window are placed loudspeakers. The total height of the minaret building from the base is around $17 \mathrm{me}$ ters.

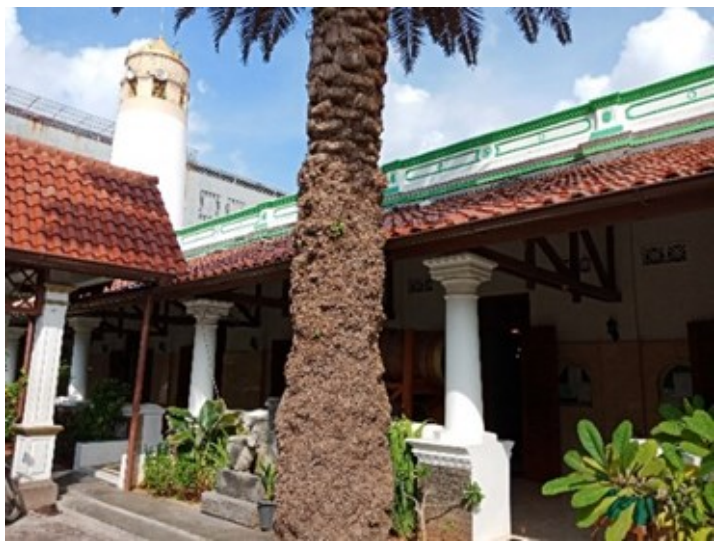

Figure 23. Mosque of An Nawier [Author]

\section{A THEORETICAL REVIEW OF ACCULTURATION}

One crucial aspect in the process of cultural change is acculturation. Acculturation is a term that in anthropology involves the concept of social processes that arise when a group of people with a particular culture are confronted with elements of a foreign culture so that foreign elements are gradually accepted and processed into their own culture, without causing loss of personality that culture [18][19]. One of the people who establish contact will completely let go of his old culture and fully accept the new culture. Cultural elements from both parties appear to be represented in this final result, although the proportions can differ from each other [2].

There are four attitudes towards it in acculturation: adoption, adaptation, synergy, and marginalization. If self-civilization (local) is weak, then what happens is adoption, which is a position that is always dictated by a stronger (foreign) civilization. If a strong 
local society faces a weak civilization from outside, adaptation will occur. If it is equally strong between local and foreign communities, synergy means that they provide equal input. Marginalization indicates that there is no contact or mixing [21][22][Figure 24].

What happens in architectural acculturation are adoption, adaptation, and synergy. Adoption occurs when forms and or elements in architectural buildings are a mixture of forms and or elements of local and non-local architecture, where non-local architectural forms are dominant to local architectural forms. Adaptation occurs when forms and elements in architectural buildings are a mixture of local and non-local architectural forms or elements. Local architecture is dominant to non-local architectural forms. Synergy occurs when forms and elements in architectural buildings are a mixture of local and non-local architectural forms or elements. There is no domination between local architectural forms and non-local architectural forms [23] [Figure 25].

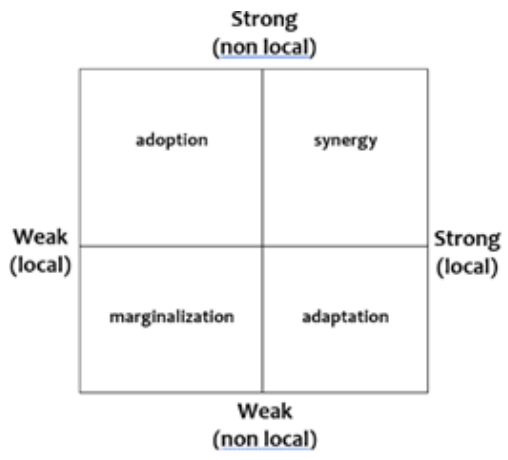

Figure 24. Diagram of acculturation

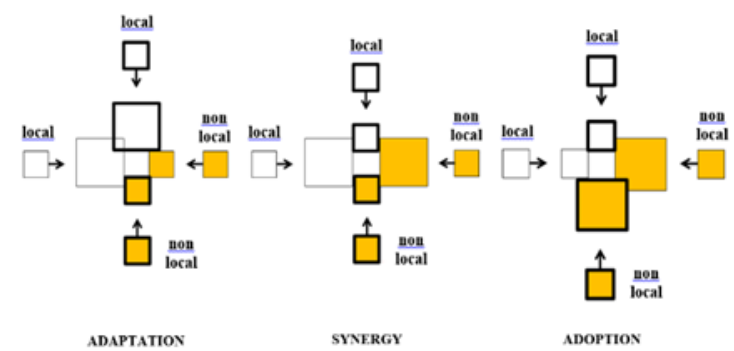

Figure 25. Diagram of architectural acculturation: adaptation, synergy, and adoption

The local architectural forms are the original forms of creation from generation to generation of ethnic groups in Indonesia, namely traditional forms of architecture [24]. At the same time, non-local architectural forms are non-original forms produced and carried by people who come from outside (foreigners). The evaluation of architectural forms' dominance is based on criteria: the area and the volume of the building form, which can be directly seen to its full potential by normal human vision.

\section{MENARA KUDUS: IS IT A MINARET OR A TEMPLE?}

If the Menara Kudus building is compared to the three temples: Sawentar, Jabung, and Bajang Ratu, on the one hand, and the Menara Kudus building is compared to the three minarets of the mosque: Banten, Sunan Ampel, and An Nawier, on the other hand, then the Menara Kudus is more similar to the temple building. The characteristics of the temple building, which is also owned by the Menara Kudus building, are as follows: (1) The shape of the building plan is square, not round; (2) the building consists of three parts, namely the foot, body, and head; (3) Building materials are bricks without plaster (the same as Jabung and Bajang Ratu temples); (4) It has an entrance that is at a certain height so that to reach it, we must pass a stair trap that is part of the building; (5) The shape of the building part is not the same between the legs, body, and head; and (6) on the surface of the walls there are several ornaments (reliefs) [Figure 26].

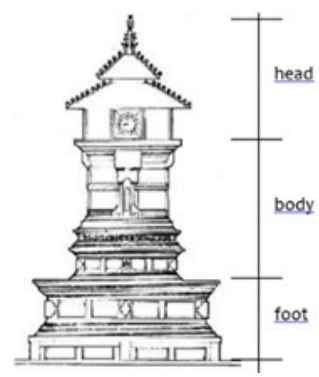

Figure 26. Sketch of Menara Kudus consists of three parts: foot, body, and head [Author]

The characteristics of temple buildings that are not owned by the Menara Kudus building are as follows: (1) Overall, the temple building material is the same (bricks without plaster or temple stone), while the Menara Kudus building, at the foot and body, it is the bricks without plaster, and at the head, it is the wooden structure; (2) Ornaments or reliefs on the walls of temples are shaped with geometric and living things motifs, while on the walls of the Menara Kudus are shaped only with geometric motifs, there are no living creature motifs; and (3) The function of the temple is to accommodate Hindu / Buddhist worship activities, while the function of the Menara Kudus is to accommodate Islamic religious activities, namely the adzan, the call to pray. [Figure 27].

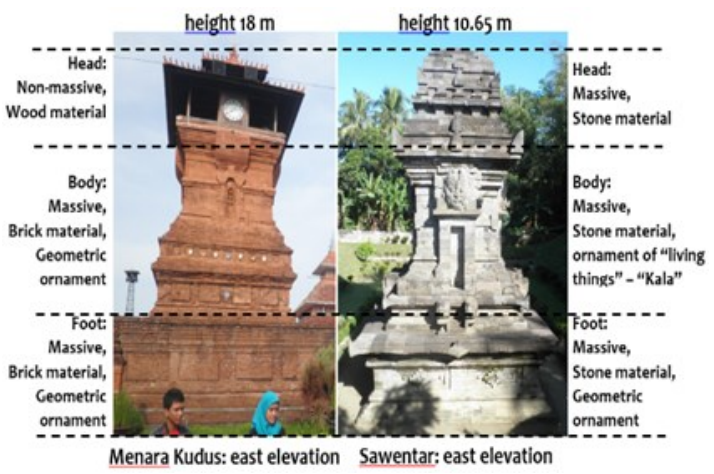

Figure 27. Comparison between Menara Kudus building and Sawentar temple 
From the analysis above, the Menara Kudus building, in the beginning, was a temple building that might not have finished its head part; The Muslims might add the wooden construction to the head part later. Meanwhile, in the absence of ornament with the living thing motifs, it could be that it had not been created yet.

\section{ARCHITECTURAL ACCULTURATION OF MENARA KUDUS}

Menara Kudus building was built as a temple, then its function was changed as a mosque minaret, with a wooden construction building with a tajugshaped roof. In the building above the minaret was placed a bedug (drum), which sounded just before adzan of the Friday prayer. Physically, the Menara Kudus building consists of two forms: the form of the temple, which includes the legs and body, and the form of the tajug building on the head; It is a product of Javanese culture. The legs and body are made of bricks without plaster, while the head part is in a wooden building. There is a crown (Memolo) at the top of the roof [25]. The temple building represents non-local architecture because it is a product of Hinduism / Buddhism that comes from outside and is carried by Indians. While the Tajug building represents local architecture because it is a product of the work of ethnic Javanese, one of the ethnic groups in Indonesia.

If it is related to its function as the minaret for adzan then here is a mixture of three cultural elements; First, the temple building represents non-local architecture because it is a product of Hinduism/Buddhism, which come from outside; Second, the tajug building that represents the local architecture because it is the product of the work of ethnic Javanese, one of the ethnic groups in Indonesia [Figure 28], and third, the function of the call to prayer - adzan, which represents non-local elements because it is a product of Islam that comes from outside. The Hindu culture is the most dominant of the three cultural elements in the Menara Kudus building. So, the acculturation of the Menara Kudus building is adoption because, in that mixing, the non-local element represented by the temple building is more vital than the local element. [Figure 29].

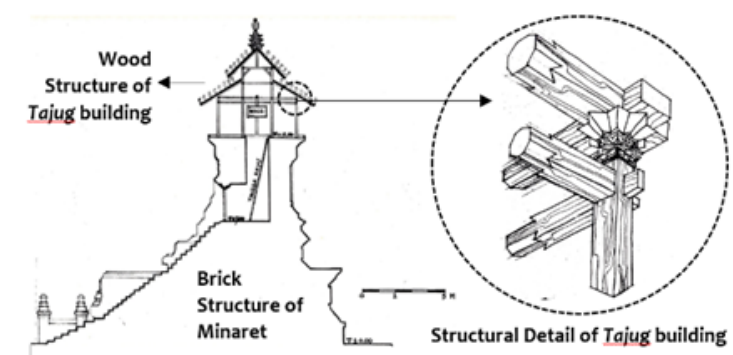

Figure 28. The Section of Menara Kudus; Tajug Building on top of the Minaret. Tajug is one of the traditional Javanese building forms [Author]

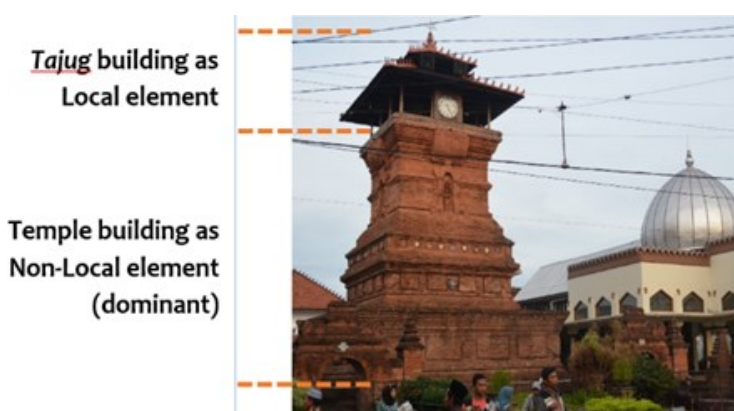

Figure 29. Architectural acculturation of Menara Kudus: Adoption, Non-Local element stronger than local

\section{CONCLUSION}

Based on its comparison with the temple building and the mosque minaret building, the Menara Kudus building is an acculturation product between Hindu culture represented by the temple building, Javanese culture represented by the tajug building, and Islam represented by the adzan function. Among these three elements, the most dominant element in Hindu culture. Acculturation is adoption, where non-local elements defined by the temple building are more prevalent than local elements.

\section{REFERENCES}

[1] J. Antoniou, Islamic Cities, and Conservation. Geneva: The Unesco Press, 1981.

[2] Ashadi, Kudus Kota Suci di Jawa, Jakarta: Arsitektur UMJ Press, 2019.

[3] Syafwandi, Menara Masjid Kudus. Jakarta: Bulan Bintang, 1985.

[4] S. Salam, The Minaret of Kudus. Jakarta: Gema Salam Jakarta, 1993.

[5] M. Romli, "Masjid Menara Kudus Studi Tentang Seni Hias Seni Bangun dan Kaitannya dengan Pola Kota," Thesis, Universitas Gadjah Mada, Yogyakarta, 1981.

[6] Soekmono, Pengantar Sejarah Kebudayaan Indonesia 2. Yogyakarta: Kanisius, 1973.

[7] R. Prajudi, A.Richard, F. Wibawa, "Kajian Tipomorfologi Arsitektur Percandian'Kayu' di Jawa," Research Report, Lembaga Penelitian dan Pengabdian kepada Masyarakat Unpar, 2014.

[8] I. N. W. Paramadhyaksa, I. B. G. Primayatna, I. G. A. B. Suryada, "Kajian Komprehensif Tentang Makna Filosofis Arsitektur Candi di Jawa," Research Report, Program Studi Arsitektur Udayana, 2013.

[9] P. Suwaryadi, Sejarah Indonesia Lama. Sala: Krida.

[10] R. Soetarno, Aneka Candi Kuno di Indonesia. Semarang: Dahara Prize, 1997.

[11] N. Bullough, Historic East Java, Remains in Stone. Singapore: Nigel Bullough, 1995.

[12] S. Darmawan, S. Daryaka, F. Mustofa, Atlas Budaya Indonesia (Edisi Candi), Meneropong Candi dari Aspek Geospasial. Bogor: Badan Informasi Geospasial, 2015. 
[13] E. M. A. Budiono, B. Supeno, R. P. N. Puji, “Nilai Edukasi Candi Jabung Kecamatan Paiton Kabupaten Probolinggo Dalam Pembelajaran Sejarah, Historia, vol. 7, No. 2, pp. 153-158, 2019.

[14] Departemen Pendidikan dan Kebudayaan, Pemugaran Candi Kidal dan Gapura Bajangratu, 1992

[15] U. Andika, "Makna Bangunan Menara Masjid Agung Banten," Prosiding Seminar Heritage, Ikatan Peneliti Lingkungan Binaan Indonesia (IPLBI) 2017, A 175-180.

[16] I. P. Nasution, "Menara Masjid Kuno Indonesia Suatu Survey dan Studi Kepustakaan," Wacana, Vol. 6 No. 1, pp. 27-40, 2004.

[17] A. S. Wirawan, B. S. Budi, "Perubahan Pada Menara Masjid Sunan Ampel Surabaya Tahun 1870-2012," Prosiding Seminar Heritage, Ikatan Peneliti Lingkungan Binaan Indonesia (IPLBI) 2017, A 491-498.
[18] W. A. Haviland, Antropologi Jilid 2. Jakarta: Erlangga, 1993.

[19] Koentjaraningrat, Pengantar Antropologi I. Jakarta: Rineka Cipta, 1996.

[20] R. Linton, Study of Man. Bandung: Jemmars, 1984.

[21] J. W. Berry, "Acculturation: Living Successfully in Two Cultures," International Journal of Intercultural Relations, 29, pp. 697-712, 2005.

[22] P. Salura, Sebuah Kritik: Arsitektur yang Membodohkan. Jakarta: Gakushudo Publisher, 2015.

[23] Ashadi, Akulturasi Arsitektur Masjid-Masjid Tua di Jakarta. Jakarta: Arsitektur UMJ Press., 2017.

[24] T. Roesmanto, Pemanfaatan Potensi Lokal dalam Arsitektur Indonesia. Semarang: Badan Penerbit Universitas Diponegoro, 2007.

[25] K. R. Ismunandar, Joglo: Arsitektur Rumah Tradisional Jawa. Semarang: Dahara Prize. 